DEMOCRATIC GOVERNANCE IN MECOUNTRIESCHALLEN.....

$\sim$ Amany A. Khodair \& Mahmoud Khalifa

\title{
DEMOCRATIC GOVERNANCE IN MENA COUNTRIESCHALLENGES AND ASPIRATIONS
}

Amany A. Khodair*, Associate professor of Political Science, Suez Canal University-Egypt. \& Mahmoud Khalifa**, Assistant Lecturer of Political Science,Suez Canal University

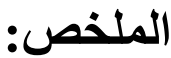

إن منطقة الثرق الاوسط وشمال إفريقيا تعتبر من المناطق التى يسودها

انظمة سلطوية تسيطر على مجريات الحكم هذة الانظمة تعية عملية الحكم

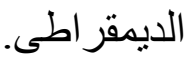

يهدف هذا البحث الى تحليل الحكم الديمقر اطى فى دول شمال إفريقا من خلال

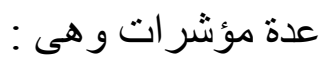
ـ حرية الر أى و التعبير -

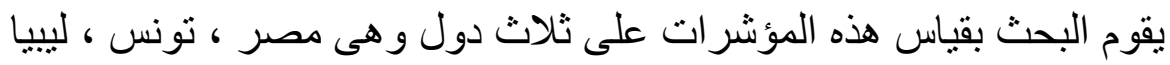

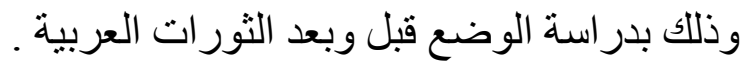


$\sim$ Amany A. Khodair \& Mahmoud Khalifa

\section{Abstract:}

The Middle East and North Africa (MENA) region is often regarded as an area that was mostly dominated by authoritarian regimes. These regimes form authoritarian constraints especially during elections - hindering political development. This usually leads genuine opposition parties and movements to form alliances, in order to make demands for reforms by these authoritarian regimes. This notion is reinforced by the fact that, in the most recent set of elections held in the region prior to revolutions that took place in countries like Tunisia, Egypt \& Libya, political parties perceived to be anti-democratic or state run have achieved important electoral victories. This article conducts an analysis of these pre-revolutionary elections in various MENA countries, namely Tunisia, Egypt \& Libya, in an attempt to discern whether or not, results of these elections contributed to the revolutions that precipitated the abrupt end of decades of political dictatorships that governed the vast majority of countries in the Mena region.

Dictatorships with corrupt military rule and the absence of institutions based on the rule of law, good governance and independent judicial systems, eventually gave way to the rise of protest against autocratic rule or political regimes prone to corruption and poor governance. The research looks at data that highlights certain patterns in the pre-revolutionary electoral process, as well as a content analysis of the constitutions of the three newly liberated countries prior to the revolutions.

The article will also raise the question of whether the sole virtue of free and just elections is enough to achieve democracy 
$\sim$ Amany A. Khodair \& Mahmoud Khalifa

(as democratic governance). It will consider whether other aspects of political reform such as the slow and steady development of political parties, civil society and interest groups as well as a better education system, are needed to fulfill the revolutions goal of political change. This question will be addressed by examining various democratic models of governance in an attempt to prescribe the best model for MENA nations seeking democratization in the aftermath of the revolutions.

Figure one shows the three main models of democracy. The most important goal in a majoritarian democracy is maximizing mass participation, the majoritarian aggregation of interests ${ }^{1}$, automatically resulting in decisions being made in a way that maximizes general welfare. This model provides criticism of the elite democracy model as it considers there to be no such thing as an elite that is not self-interested or able pursue the good of the masses. It also criticizes the liberal democracy model as it argues that an emphasis on individual rights is used to limit government in order to protect small, privileged groups.

While the elite democracy model focuses on general welfare which requires an elite capable of pursuing the long-term interests of society it actually values low mass participation.

This notion of democracy challenges the liberal democracy model on the basis that it places undue focus on individual rights, limits a government's ability to pursue the general welfare of the community. The elite model also suggests that the majoritarian mode. 
$\sim$ Amany A. Khodair \& Mahmoud Khalifa

The liberal democracy model is based on the belief that the most important goal is to protect individual rights and although this model does not prefer low mass participation but it may be willing to accept it as long as individual rights are protected. This model inherent institutional and political pressures exist ${ }^{2}$ and criticises other models because, if unchecked, elites may use their power to infringe the rights of individuals, the majority and of minorities (tyranny of the majority). The majoritarian model responds to criticism with the belief that the masses can gradually learn to become better democratic citizens if given a meaningful opportunity to do so.

Establishing more effective democratic governance is the greatest challenge facing most MENA countries, particularly after Arab Spring. Democratic governance requires institutions to uphold it, a civil society to promote it, the rule of law to enforce it, a free press to articulate it and an independent judiciary system to oversee properly constituted political parties. It is only after all this has been achieved that a democracy should ensure fair and free elections, appropriately monitored by independent observers $^{3}$.

We will now consider some of the necessary components for successful democratic governance, provided by governments that succeed in maintaining a reasonably high quality of democratic practice; help their countries advance economically (fighting against poverty), control of corruption, provide citizen security, freedom of expression, and free $\&$ fair elections ${ }^{4}$. These indicators were chosen from a wide range of indicators looking to criticism that constitutes the most potent force driving social 
DEMOCRATIC GOVERNANCE IN MECOUNTRIESCHALLEN.....

$\sim$ Amany A. Khodair \& Mahmoud Khalifa

change in the region, criticism of inept government policies and rampant corruption have, most likely, contributed to calls for revolt, in other parts it has led to calls for more autonomy to pursue goals and aspirations brought into focus by rising levels of education and globalization ${ }^{\mathbf{5}}$.

\section{Models of Democracy}

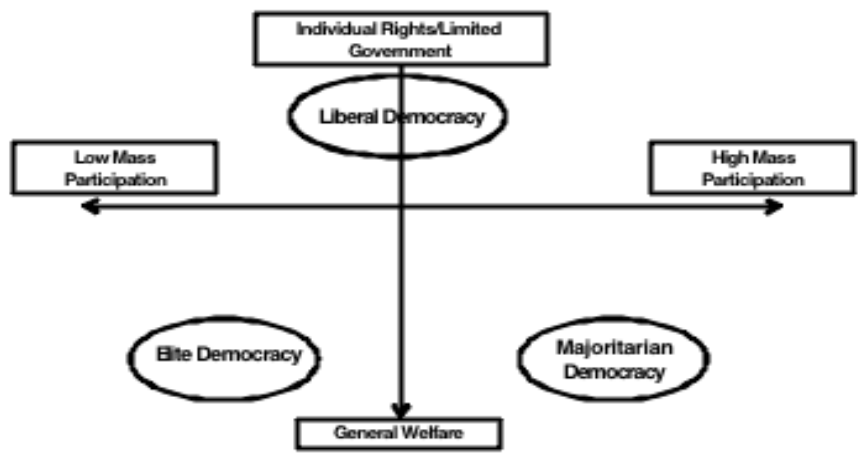

Figure 1

\section{First : Poverty Reduction}

International organizations define poverty as "the economic state in which the individual loses the sufficient income for attaining the least levels of health care, food, clothing, education and all what is considered necessary needs for insuring a descent level of life". Since 1991, the World Bank has defined international poverty levels as the percentage of a country's population living below $\$ 2$ a day, with extreme poverty including those living below $\$ 1$ a day in accordance with the PPP $^{6}$ (Purchasing Power Parity) terms ${ }^{7}$ The World Bank also considers the countries in 
$\sim$ Amany A. Khodair \& Mahmoud Khalifa

which an individual's average annual income is less than $\$ 600$ to be poor countries, then, reduced it to 400 dollars or its equivalent.

There are several negative economic, social and political impacts contributing to increased levels of poverty. The economic effects include increased levels of debt and personal loans. In addition, national income is concentrated on feeding the hungry instead of development and investment as well as the reduction of production levels. The social effects are literacy, illiteracy, spreading diseases, increasing death rates and also increasing crime rates among young men and women. This study concentrates on the important political effects of poverty, including political despotism; one of the major problems is power of money and authority. External relations can also create problems, particularly when subject to conditions given by countries that grant loans and assistance. In addition, other problems such as political disturbance and unrest may happen. Research indicates that poverty is one of the main reasons for disorder and disturbance with the majority of political problems relating to poverty and deprivation while rich countries with a strong welfare system allow the majority to live in peace and stability.

We will now address poverty rates in Tunisia, Libya and Egypt, but we must first note that MENA countries recorded the most rapidly increasing inequality rates, which in turn increases the rate of poverty. ${ }^{8}$ 


\section{Figure2: Source ${ }^{1}$}

FIGURE 2

Poverty Trends, Globally and by Region, 1981-2005

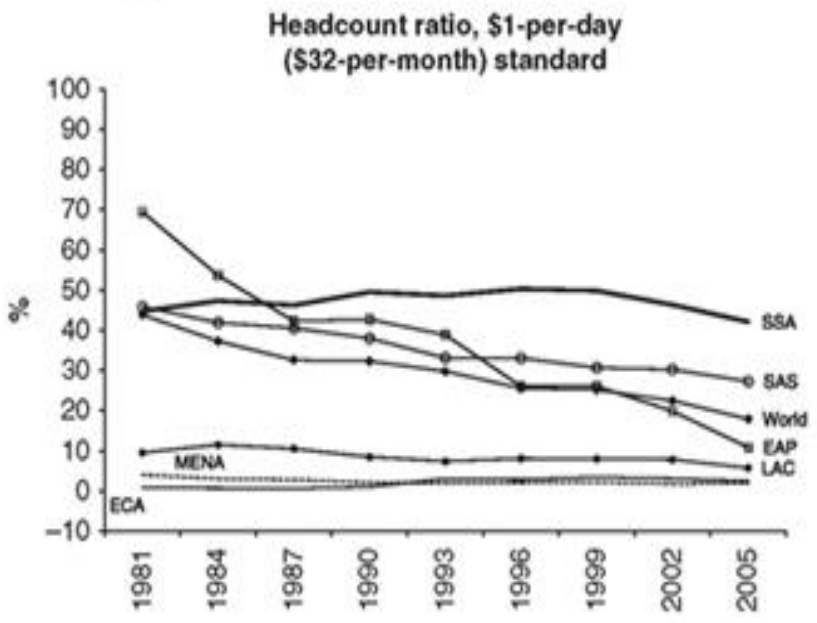

Notes: EAP = East Asia and Pacific; ECA = (Eastern) Europe and Central Asia;

LAC = Latin America and the Caribbean; MENA = Middle East and North Africa;

SAS = South Asia; SSA = Sub-Saharan Africa.

DATA SOUACE: World Bank (2009).

\section{Tunisia}

Poverty, along with unemployment and illiteracy, was one of the three main problems facing Tunisia before the revolution. Yet the issue was completely ignored by the ousted president despite speeches asserting his determination to eradicate inequality ${ }^{9}$.

The National Institute of Statistics (NIS) in Tunisia stated that the percentage of the population in poverty $15.5 \%$ in 2010 
DEMOCRATIC GOVERNANCE IN MECOUNTRIESCHALLEN.....

$\sim$ Amany A. Khodair \& Mahmoud Khalifa

$(23.3 \% \text { in } 2005 \text { and } 32.4 \% \text { in } 2000)^{10}$, meaning about 1.6 million Tunisians are classified as poor. In addition, extreme poverty reached $4.6 \%$ in 2010 against $7.6 \%$ in 2005 and $12 \%$ in $2000 .{ }^{11}$

After the revolution, Tunisian formal reports estimated that the poverty percentage in the countries with $24.7 \%$ depending upon international scale determining poverty limit with 2 dollars per one individual daily. This percentage is raised especially in the western regions of the countries that witnessed continuous protests for improved living standards, development of social services and infrastructural improvements. The NIS stated that "the individual is considered poor when his annual consumption level does not exceed the poverty line determined at 1277 Dinars (about \$850) in major cities and 820 Dinars (about \$550) in the non-local environment rural areas".

The NIS determined the extreme poverty line with "757 Dinars (505 Dollars) per individual in the major cities against 571 Dinars (380 Dollars) in the local regions.

\section{Libya}

A study prepared by General Popular Committee Secretariat for planning and finance indicates the economic and social position for Libya by stating that the number of its population below the poverty line has increased from about 605,000 in 1993 to about 739,000 in 2001. In addition, the 2010 developing objectives report in Libya issued by the United Nations assured that Libyan society has no individual suffer from poverty and hunger considering the limited income persons upon the minimum limit of food. The poverty level was determined at 
$\sim$ Amany A. Khodair \& Mahmoud Khalifa

336 Dinars per month (about \$266). Libya had attempted to establish a fund that is focused on those whose income is less than 200 Dinars (about \$158), with the aim of getting rid of poverty.

The percentage of those in poverty, after the $19^{\text {th }}$ of February revolution reached to more than $40 \%$ according to transformational national council estimates. Hence, the counselor Mostafa Abdel Galil, chairman of the transformational council granted the people a grant of 2000 Dinars for each Libyan family and 200 Dinars for each child. Salaries were increased starting from 01/01/2013. That is by submitting law of increasing the housing bonus and family bonus.

\section{Egypt}

In Egypt, a large percentage of the population (almost $35 \%$ ) live fairly close to the poverty line ${ }^{12}$. In accordance with local statistics (Central Agency for Statistics), the poverty averages indicate to $25.2 \%$ whereas the International Bank states that it was at $52 \%$ in 2010. In addition, the local statistics indicate that the poverty average in 2009 was $21.6 \%$, which is approximately 18 million. ${ }^{13}$ Statements made by the Egyptian Central Organization for Statistics reveal that the minimum limit of poverty is 256 Egyptian pounds, (about \$42) per individual per month whereas the higher limit of poverty saves monthly income per individual reaches the average of 334 pounds, meaning 55 Dollars.

The average poverty levels increased after the 25th January revolution as a result of retreating growth and tourism 
$\sim$ Amany A. Khodair \& Mahmoud Khalifa

and lack of direct foreign investment flows. Then about 2000 factories closed, contributing to a remarkable rise in unemployment and loss of income for these workers. This supported by the information center and supporting decision making that indicated raising poverty averages after the revolution to $25.2 \%$.

Lastly, poverty impedes human development and is considered to be one of the main obstacles to democratic governance. So, the social structuring support needed for freedom and good governance is reinforced by a widening scale of medium and high society categories stipulating that the high category would add to the requirements needed for and supporting the civil and political society organizations. It is remarkable that, at present, between the richest social classes distracting general work especially the political objection for protecting its properties and its distinguished social position in a way that makes freedom from poverty important in the societies striving for freedom when concerned with general field threatens the capability of satisfying the basic needs.

The previous three examples countries show the remarkable rise in the poverty level in a way that leads to the increase of the weakest social classes. For this reason, it is feared that the class structuring in these three countries does not support democratic governance at present.

\section{Second: Free and Fair Elections}

Before the revolution, the legislative elections were held in 2009 in Tunisia on Sunday 25 October. They were the fifth legislative elections during the reign of the previous president 
DEMOCRATIC GOVERNANCE IN MECOUNTRIESCHALLEN.....

$\sim$ Amany A. Khodair \& Mahmoud Khalifa

Zein El-Abdeen Ben Ali after elections that took place in 1989, 1994, 1999, 2004. They are held on the same day as the presidential elections. The ruling Democratic Constitutional Coalition won in all constituencies. The political parties supporting the policies of President Ben Ali won 51 seats out of 53 allocated for the opposition while the renewal movement that supported Ben Ali previously attained only two seats.

The opposition democratic coalition party for work and freedoms that participated for the first time did not attain any seat, whereas the progressive Democratic Party withdrew before the elections. The Interior Minister Rafeek Belhaj described these elections as being transparent and democractic. ${ }^{14}$ On the other hand, Human Rights Watch questioned the freedom, transparency and elections fairness. ${ }^{15}$ Another aspect restricting the freedom of citizens with regards to political affiliation is apparent in the prohibition of radical Islamic movements. ${ }^{16}$ It is worth mentioning that voting participation reached $89.45 \%$, and the repetition of elections with similar rates of participation is notable and raises questions concerning their validity.

In Libya, it was a completely different story, In the age of the late President Muamar Gaddafi, this tyrant regime did not provide any opportunities for Libyans free participation in a democratic way and determined their destinies and choose the method and style of governance for them. It was clear that since the first weeks of the military coup d'etat that brought lieutenant Gaddafi to power in September 1969 that there was no new military program in Libya- you mean it would stay how it was?? or any intention of creating a political and democratic regime, 
$\sim$ Amany A. Khodair \& Mahmoud Khalifa

organizing general elections or civil government. In spite of that, areas, fields and cities of Libya were full of extremely awful mottos support and describe the (representing democratic or parliamentary) political multiplication with lying and betrayal.

Egypt has been, over the past few decades, exercising an undemocratic electoral process, making it impossible to establish an electoral system characterized bycompetitiveness, transparency and desired fairness. So there was little hope of filling the absence of supervisory guarantees, adjusting the performance of the electoral process; starting with correcting official voters list and making sure that it complies with true reality, neglecting to omit incorrect names in it, and removing the names of deceased citizens and migrants who had left the country - as they did not have the right to vote prior to the revolution - these names were kept in order to be voted on their behalf in under what was called "Blacking the ballots or stuffing boxes" , they were also used by some influential candidates of the dissolved National Democratic Party or their representatives who voted collectively in their favor, and with the support of the state institutions ... etc.,

In 2010, the independent organization, Freedom House described Egypt as "not free", and the regime freed Ayman Nour Hosni Mubarak's main challenger in the 2005 presidential election, who served three years in prison, and lawmakers approved legislation that would reserve 64 seats for women in the lower house of parliament. However, the regime avoided substantial political reform and continued to abuse civil liberties, maintaining 
DEMOCRATIC GOVERNANCE IN MECOUNTRIESCHALLEN.....

$\sim$ Amany A. Khodair \& Mahmoud Khalifa

pressure on the opposition Muslim Brotherhood as well as independent journalists ${ }^{17}$. Thus we can emphasize that the history of the electoral process in Egypt before the revolution was characterized by manipulation of the public, and was far from democratic .

Existence of an independent body or National Electoral Commission for the supervision of elections and the existence of secret elections, sort publicly, and freedom of choice.

There was no independent authority to oversee elections in Tunisia before the Tunisian revolution so the government supervised both the legislative and presidential elections. Elections were not confidential, the counting of votes was not public and there were no transparent elections boxes necessary to ensure transparency. In Libya, the Constitution of the states was cancelled during the first military statement, leaving no room for any electoral body never mind an independent one. Egypt also did not have an independent body observing and administrating the electoral system.

\section{Re-determining electoral constituencies}

The presence of obstacles and a lack of clarity in determining the constituencies and regulators was a dominant theme in all three countries.

\section{Media and communication}

There was no respect for media institutions and freedom of opinion as well as there are many regulators constraints on free press. The Human Rights report stated on the December 23, 
$\sim$ Amany A. Khodair \& Mahmoud Khalifa

2009 that Tunisian authorities should cancel the conviction of journalists Taoufik BenBrik and Zouhair Makhlouf after unfair trials and release them immediately. She added that the government should also investigate the attempted attack on another journalist, Selim Boukhdhir, and stop the further harassment of journalists.

On the other hand, Libya witnessed sharp restrictions upon freedom of opinion and expression and confiscation of independent and even semi independent journals. The issue was ended by a speech by Gaddafi who seized capacities of the Libyan people in the name of revolution on the 16th of April 1973. However, the issue was then extended resulting in the marginalization of the judiciary and the freezing of the council of revolutionary leadership before cancelling the council and exchanging it with his family.

After the revolution, during the first Tunisian elections that followed the revolution, 100 political parties participated. The Islamic renaissance party attained the most seats attaining 89 seats in the Parliament, but it did not achieve a majority, with only $30 \%$ of the votes. ${ }^{18}$ Voter participation reached $90 \%$ in the elections held after the revolution, with a choice between 10,937 nominees. ${ }^{19}$ The highest participation (as nominees or voters) was amongst those in the 21 to 30 year old age category. Women represented $46 \%$ of those registered administratively and occupied 59 seats out of total 217 seats in establishing national council. 
$\sim$ Amany A. Khodair \& Mahmoud Khalifa

The new Tunisian political scene has not yet experienced the barren "ideological" relationship that was the norm for political parties from the time of independence. It did become ruled by a relationship described by Pragmatic approach. It is a factor that made elective and political alliances to form quickly, especially at the among parties on the left whose coordination was demonstrated by "updated democratic pole" that submits elective program "purely secular". In spite of this "secular" elective program but the updated democratic pole came in the fourth rate. 20

After the Egyptian revolution a military council replaced Mubarak's ouster.

Marshal Tantawy who was initially welcomed but soon faced criticism for continuing human rights violations, harassment of activists and nongovernmental organizations, and apparent attempts to postpone a transfer to civilian rule. Three rounds of parliamentary elections, monitored by the judiciary and featuring previously outlawed political parties, began in late November but were not scheduled for completion until early January. These elections were described by Freedom House as "not Free", in $2012^{21}$.

The Muslim Brotherhood, the Islamist group that was the primary opposition to Mubarak's rule, won nearly half of the seats in Parliament in the January 2012 elections. ${ }^{22}$ In March, despite having earlier stated that it would not seek the presidency, it announced Mohamed Morsi as its candidate to 
DEMOCRATIC GOVERNANCE IN MECOUNTRIESCHALLEN.....

$\sim$ Amany A. Khodair \& Mahmoud Khalifa

represent its newly formed Freedom and Justice Party (FJP), who won the elections with a $51.7 \%$ majority.

In Libya, elections for the national assembly were held in July 2012 with a reported turnout of approximately $60 \%$ of registered voters. $^{23}$

Existence of an independent body or National Electoral Commission for the supervision of elections and the existence of secret elections, sort publicly, and freedom of choice.

After the Tunisian revolution, the National Constituent Assembly (NCA) was elected on October 23, 2011. Following democratic,free and transparent elections witnessed by international observers, the independent body had the authority to manage an independent electoral process and it was established in accordance with decree number 27 created in 2011. The body authorized the preparation of the elections, supervision, control and arbitration of disputes after the elections. According to the Secretary-General of the independent commission that organized the vote, more than $90 \%$ voted out of the 4.1 million people who registered. $^{24}$ Also, it stated the following, with regards to the existence of national and international observers:

- National observers: 13, 800 certified national observers existed in $70 \%$ of the voting offices.

- International observers: the international missions dedicated about 600 international observers.

In Libya, the National Transitional Council (NTC) established the National Council for Civil Liberties and Human Rights with the authority to receive complaints on violations of human rights and to file cases in court, this National council for fair elections 
$\sim$ Amany A. Khodair \& Mahmoud Khalifa

declared that post-revolution that it has revised 1,796 forms for the nominees of elections (general national conference of parliament). It approved 1,720 of them, only refusing 76 , that did not meet the national criteria now required for Libyan elections.

Thus, there are signs of integrity in the electoral process due to the existence of a modern constitution that provides the right to all citizens to run for key positions in the Libyan government.

Libya held its first election in over 50 years on July 7, 2012. A total of 2,051 candidates, including 84 women took part in the race. Over 1.7 million people voted and 33 women were elected to the 200 members of the General National Congress, replacing the National TransitionalCouncil ${ }^{25}$.

However, the issue of integrity and fairness of the elections in Egypt has sparked controversy and conflict between different political trends after the revolution of the 25th of January and this, of course, was a result of previous unfortunate events that prevailed under the former regime like fraud and flagrant violations which had a negative effect on the political environment. Therefore Egyptians only saw the possibility of fair or semi-fair elections through trust in the judicial body. Even though most Egyptians kept great confidence in the integrity of the Egyptian judiciary, they believe that the judicial supervision of the elections will not be the only factor that ensures electoral fairness.

\section{Media and communication}

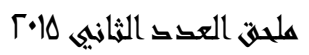


DEMOCRATIC GOVERNANCE IN MECOUNTRIESCHALLEN.....

$\sim$ Amany A. Khodair \& Mahmoud Khalifa

The present elective campaign in Tunisia was distinguished by the emergence of similar elective programs with the nominations list exceeding 1,500. These many lists meant adding to the parties number that exceed 1500 party and independent lists included more than 10,000. These lists and parties made the political scene as a seat at two sides. The first one in the way of thoughtful creation of lists.

The second one concerns the inability to look up determine future elections and the structure of the establishing council. Its main task is forming a new constitution and legitimacy using establishments of the state. ${ }^{26}$ Then respecting freedom of opinion, expression and freedom of the press and multiplication in means of media and communication since the revolution. The establishments authorized for the control and restriction of the press were removed after these restrictions was a basic matter in the reign of Ben Ali. Also, the Tunisian media and communication content was removed. It started to tackle updates of matters and some subjects ignored by means of media escaping from the control became a thesis for discussion permanently without condition or restriction in spite of existence of self-control for the communicators especially concerning corruption file that touches relatives of the previous President who remained in the state.

After a license was authorized to the international organization "reporters without borders", they opened an office in Tunisia - another move to show the will to strengthen journalism and media freedom in the state. 
$\sim$ Amany A. Khodair \& Mahmoud Khalifa

\section{Third: Corruption}

The world bank defines corruption as "the misuse of public authority to achieve private benefits or interests", and if we want to comprehend the concept of corruption we should turn to H.A.Brasz who went on to explain it as the synonym of "abusive force", which means the use of force to achieve purposes other than the purpose of granting the legitimate use for such a force.

Thus corruption in such a sense has several negative effects, i.e.:- favoritism, nepotism, partisanship and tribal bias which leads to the distortion of the administrative system. This distortion is represented in a lack of morals, political fraud in the elections, and the use of force in order to reach power. This leads to the existence of a ruling class which is corrupt and does not reflect the will of the people, as well as other forms of corruption like paying bribes to senior officials in order to win tenders and contracts for large scale construction which leads again to extreme distortion of the state's infrastructure.

Another negative effect is the phenomenon of blackmailing carried out by senior officials as well as complexities in procedures and routine or red tape that may lead to the absence or lack of capital likely to invest in the country ${ }^{27}$.

The spread of the phenomenon of corruption and the widening of its scope also represents a serious challenge facing development as it causes immense deformities and disabilities, that may lead to unrest and revolutions. This was clearly shown in Egypt, Libya and Tunisia for in recent decades illegitimate cooperation occurred between the political system and the security system which is represented in security organisations 
$\sim$ Amany A. Khodair \& Mahmoud Khalifa

such as the SSI and the central security sector, which were accused of killing peaceful demonstrators at the beginning of the people's revolution.

Some indicators of corruption may include the following: Prevalence of sudden wealth in the society, as well as bribery to the extent that it becomes one of the requirements of completing documents in any transaction ${ }^{29}$.

Favoritism and loyalty to friends and family with regards to filling jobs and positions rather than being based on merit, competence, skill, professionalism and integrity30.

Absence of the principle of equal opportunities in employment, control is just a formality as a devices, performance and role.High ratios of corruption in any society are considered as evidence of poor government control, weak implementation of the law, and the absence of legislation. The promotion of political corruption may also be a result of the absence of standards in the organizational foundations, legal and applied. It is also seen in those seeking individual benefits at the expenses of the common good, leading to abuse of public office and state resources, leading to the breakdown of the essential role of the government in eliminating the principle of justice, equal opportunities, efficiency, and integrity, as key factors when holding public office.

Transparency International, an organization leading the fight against corruption, introduces three measurements of corruption, updated annually, these are the: 
DEMOCRATIC GOVERNANCE IN MECOUNTRIESCHALLEN.....

$\sim$ Amany A. Khodair \& Mahmoud Khalifa

Corruption Perceptions Index (based on expert opinions on the conditions of countries with regards to corruption).

Global Corruption Barometer (based on surveys on public attitudes and experience with corruption.

Bribe Payers Polls (which looks at the willingness of foreign companies to pay bribes).

\section{Tunisia}

Tunisia appears towards the end of the corruption index, as can be seen in the following table:-

Table \& figure 4:- Index of Transparency International index companies to pay bribes).

Figure 4 source $^{31}$

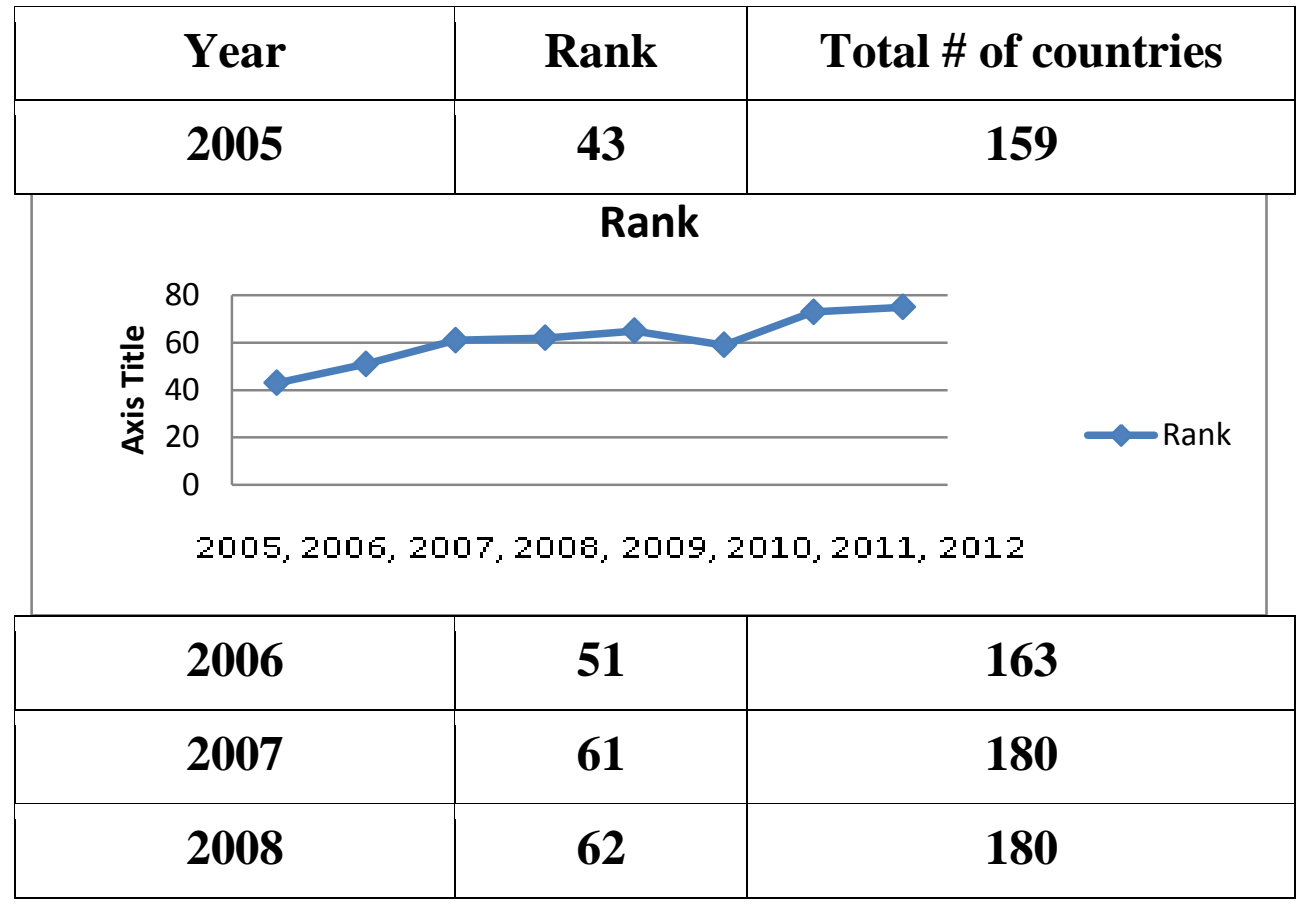

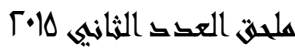


DEMOCRATIC GOVERNANCE IN MECOUNTRIESCHALLEN.....

$\sim$ Amany A. Khodair \& Mahmoud Khalifa

\begin{tabular}{|c|c|c|}
\hline 2009 & 65 & 180 \\
\hline 2010 & 59 & 178 \\
\hline 2011 & 73 & 183 \\
\hline 2012 & 75 & 176 \\
\hline
\end{tabular}

Despite the delay of Tunisia in the International Classification it is among the least corrupt Arab countries. Also, despite the fact that its classification fell two ranks in 2012 it is a positive sign as the number of countries subject to classification dropped by seven countries.

\section{Libya}

Libya appears late in order of the corruption index, and can be seen in the following figure and table:-

A table showing the level of corruption in Libya according to the index released by Transparency International (TI).

It is noted here that Libya was the exception to the countries that have experienced revolutions as it had an improved ranking after the revolution, moving from 168 to 160 .

\begin{tabular}{|c|c|c|}
\hline Year & Rank & Total \# of Countries \\
\hline 2005 & 117 & 159 \\
\hline 2006 & 105 & 163 \\
\hline 2007 & 131 & 180 \\
\hline 2008 & 126 & 180 \\
\hline 2009 & 130 & 180 \\
\hline
\end{tabular}

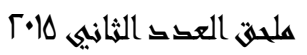


DEMOCRATIC GOVERNANCE IN MECOUNTRIESCHALLEN.....

$\sim$ Amany A. Khodair \& Mahmoud Khalifa

\begin{tabular}{|l|c|c|}
\hline 2010 & 146 & 178 \\
\hline 2011 & 168 & 183 \\
\hline 2012 & 160 & 176 \\
\hline
\end{tabular}

2005, 2006, 2007, 2008, 2009, 2010, 2011,

Figure5

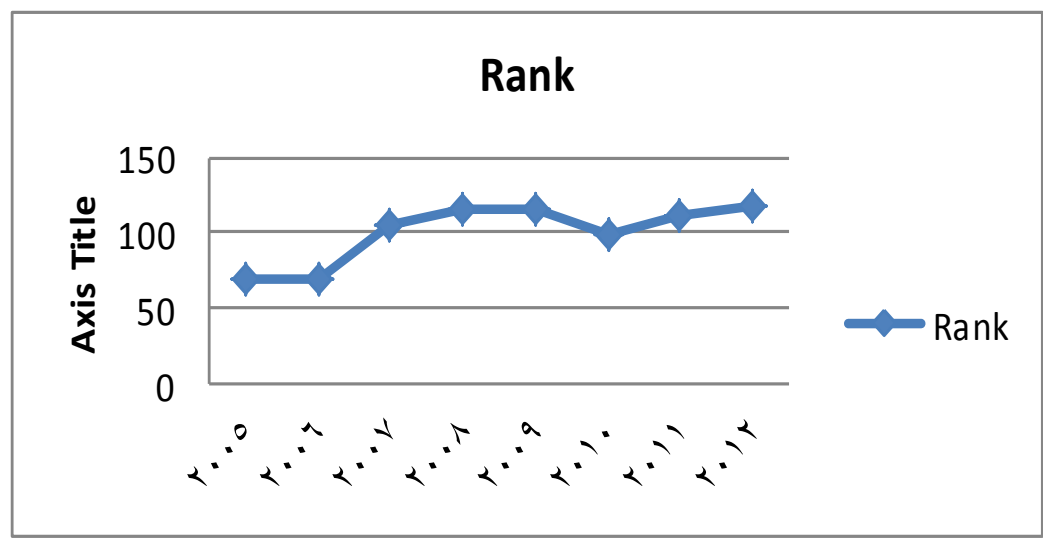

\begin{tabular}{|c|c|c|}
\hline year & Rank & Total \# of Countries \\
\hline 2005 & 70 & 159 \\
\hline 2006 & 70 & 163 \\
\hline 2007 & 105 & 180 \\
\hline 2008 & 115 & 180 \\
\hline 2009 & 115 & 180 \\
\hline
\end{tabular}

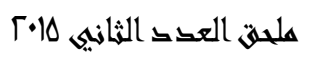


DEMOCRATIC GOVERNANCE IN MECOUNTRIESCHALLEN.....

$\sim$ Amany A. Khodair \& Mahmoud Khalifa

\begin{tabular}{|c|c|c|}
\hline 2010 & 98 & 178 \\
\hline 2011 & 112 & 183 \\
\hline 2012 & 118 & 176 \\
\hline
\end{tabular}

\section{Egypt}

Egypt's low rank appears on the corruption index released by Transparency International (TI), and can be seen from the following table

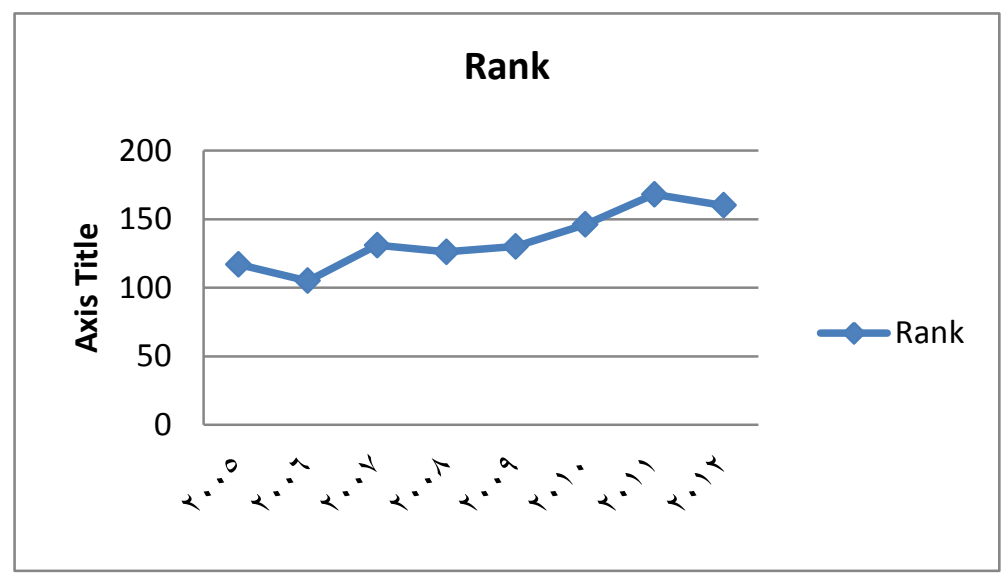

2005, 2006, 2007, 2008, 2009, 2010, 2011,

Table shows the order of Egypt's corruption index of Transparency International

Figure 6 It is highly notable here how high rates of corruption $^{32}$ seem to be one of the features of the Egyptian political system in all the years under analysis, and this is especially obvious in recent years. 
DEMOCRATIC GOVERNANCE IN MECOUNTRIESCHALLEN.....

$\sim$ Amany A. Khodair \& Mahmoud Khalifa

\section{Fourth: Freedom of opinion and expression}

The true measure of progress of any nation, people, community or state lies in the extent of its respect for freedom of expression as a key pivot in the human rights cause as well as measuring the standard of credibility of nations, peoples and communities.

The Declaration of Human Rights gave great care to freedom of opinion and expression in several articles i.e. it asserted in its' first article that every human being is born free, as well as Article II that stressed on human freedom of belief or in the adoption of views or opinions as well as article XIX " Everyone has the right to freedom of opinion and expression; this right includes freedom to hold opinions without interference and to seek, receive and impart information and ideas through any media and regardless of frontiers" ${ }^{33}$.

The public perception of freedom of expression is considered a cultural issue, even in authoritarian regimes where democracy is out of the public debate and keeps talking about freedom of expression as a vital issue facing them.

Freedom of expression and opinion depends on the tolerance of ruling regimes to criticism, and to the extent of comprehending Democratic thought which empowers society and the press (media) - known as the fourth authority, offering it the force to monitor the situation internally in any country. A virtue which is missing in ruling regimes of Tunisia, and Libya, and Egypt, where they still rely on enforcing authoritarian ideology that establishes the concept to totalitarianism, and lack of acceptance of the opposite opinion. 
DEMOCRATIC GOVERNANCE IN MECOUNTRIESCHALLEN.....

$\sim$ Amany A. Khodair \& Mahmoud Khalifa

And in spite of the presence of several articles in the constitutions of Egypt and Tunisia, to ensure freedom of opinion and expression, it did not exceed the formal framework to space of application, many abuses of freedom of expression in these countries, preventing the criticism of the rulers, and many writers or journalists were exposed to prison or torture.

\section{Tunisia}

In 2005, 13 members of the freedom of expression and opinion observer group (TMG) IFEX-TMG met, to shed light on the serious and epidemic violations of freedom of opinion and expression, including Internet censorship which the Tunisian Internet Agency spent a lot of money to activate it, the group also observed that security forces followed an unconventional pattern of police abuse, where all voices calling for change and political reform were chased and silenced with extreme violence, the group has documented several incidents during the prerevolutionary period, where police attacked journalists who were covering any demonstrations or riots.

This lead to the witnessing of several setbacks with regards to freedom of expression in Tunisia, where Tunisia was ranked the 145 in the world in terms of freedom of expression by the classification of the Human Rights Council.

As stated in the annual report of the Cairo Institute for Human Rights Studies, which deals with monitoring and analyzing the human rights situation in Tunisia after the revolution, that Tunisia is most likely to engage in a serious process of democratic governance and that the military institution helped in achieving that because it did not have a political 
$\sim$ Amany A. Khodair \& Mahmoud Khalifa

project. This gave the chance to the strong alliance of revolution, trade unions and human rights movements as well as other political forces to fill the political power vacuum.

Especially when the transitional stage in Tunisia was accompanied with a package of legislations aimed at ending restrictions on freedoms, including press and media, and freeing the work of NGOs, and the freedom to form political parties.

These changes lead to Tunisia being ranked 115 in the report of the Organization of freedom House in terms of freedom of opinion and expression (moved up 30 ranks after the Jasmine Revolution) and shifting Tunisia from the category of "states restricting freedom of press" to "states with partly free press" ${ }^{34}$.

\section{Libya}

The Libyan people were exposed to a serious of violations for four decades - the reign of Gaddafi - represented in the lack of freedom of opinion and expression when Libyan people from no political freedoms to the point that democracy was considered religiously forbidden "haram" or superstition, where the political arena suffered from complete vacuum due to the absence of Constitution, rule of law and the lack of ability to form political parties and unions, making the tribe the main national umbrella, where blogging about politics was almost impossible because any criticism was interpreted by the security forces as criticism of the head of the system which was immediately suppressed violently.

A situation that has not changed as expected after the Libyan revolution, with regards to the field of freedom of opinion 
$\sim$ Amany A. Khodair \& Mahmoud Khalifa

and expression. The Freedom House Organization voiced concern regarding the issuing of Law No. 65 of 2012, which was recently released by the general National Congress in a bid to organize the right to demonstrate peacefully, while acknowledging positive elements of this law, but the Human Rights Council saw that some of the articles are contradictory in the law governing the freedoms and restricting them in the same time, for example establishing a committee of regulators responsible for maintaining order during the demonstration, which violates international standards, which require that the state should bear the responsibility to maintain public order and safety of demonstrators and others alike.

The Human Rights Council, and the freedom House Organization places Libya (after the revolution) at the rank of 155 in the classification of states to freedom of opinion and expression, in the category of "partly free countries" ${ }^{35}$ after they were rated "not free" before the revolution.

\section{Egypt}

Although the 1971 constitution included many articles that guarantee freedom of opinion and expression and the press but the practice has made those freedoms restricted, because the constitution declared the existence of freedom, but left the organization and determining the conditions of exercise this freedom to the law - particularly - the Penal law, thus may Egyptian laws came full of restrictions on freedom of opinion 
$\sim$ Amany A. Khodair \& Mahmoud Khalifa

and expression, resulting in Egypt coming in the rank of 146 in terms of freedom of expression and by the human rights Council but an improvement was realized by freedom house organization, In 2012, which considers Egypt "partly free" with regards to freedom of speech and expression ${ }^{36}$.

After the revolution, other positive signs regarding freedom of opinion and expression could be observed represented in the opening of the Cairo International Book without supervision of any kind, for the first time in years, the Ministry of Culture promoted the freedom of opinion and expression and the revolution that made freedom one of the demands to be met in all areas especially in the field of culture, thought and the arts.

Another important achievement with regards to rights and freedoms in Egypt, is the partial lifting of the Emergency Law. Finally, the struggle for freedom in Tunisia, Libya and Egypt after the revolution is still in its preliminary stages but an important variable to be noticed is the fall of the barrier of fear from terrorizing of religious factions that were lobbying for preventing and blocking freedom in the name of religion, especially after the entry of these factions in the field of politics legally, reality became different with fewer restrictions on the freedom of opinion and expression.

\section{Conclusions}

Breaking the poverty cycle in MENA countries is a hard task that will have to be a long term process in which both citizens and governments should respond to social, economic and political opportunities within local circumstances, known as micro-level approach for sustainable change. 
$\sim$ Amany A. Khodair \& Mahmoud Khalifa

Concerning fair and just elections, we can now reach the conclusion that fair elections in MENA countries during the period after the revolution depends mainly on the role of the people in standing in the face of any violations or attempts to manipulate the outcome of elections, and the process of conflict management between different political forces as well as the ability of these organizations to stand in the face of different violations. In addition to demanding genuine constitutional and legislation amendments.

If we look to the Corruption indicator, we could conclude here that there are several Common Factors in the three countries Tunisia, Libya and Egypt that led to the spread of corruption and was consequently the major cause of the occurrence of revolutions, including:

- The absence of "Rule of Law" and its weakness in front of corrupt political leadership ${ }^{37}$.

- Favoritism and bribery within government agencies, which led to unequal opportunities.

- Complete absence of transparency in decision-making relating to the affairs of these countries.

- Lack of accountability of government officials.

The negative role of the media in spreading the ideas that contribute to the stability of the system and cover up corruption.

And finally the severe decline in living standards and high rates of poverty.

There are also special factors that led to the spread of the phenomenon of corruption in each state, for example in Egypt 
DEMOCRATIC GOVERNANCE IN MECOUNTRIESCHALLEN.....

$\sim$ Amany A. Khodair \& Mahmoud Khalifa

and Tunisia there was the dominance of the ruling elite and business community.

Also part of Egypt's privatization policies and the transformation of public sector companies into private companies, plagued by this policy of corruption leads to the evaluation of companies grossly in favor of some investors, whether they are domestic or foreign. In addition, there are substantial differences in wage levels among segments of Egyptian society.

\section{Democracy a process}

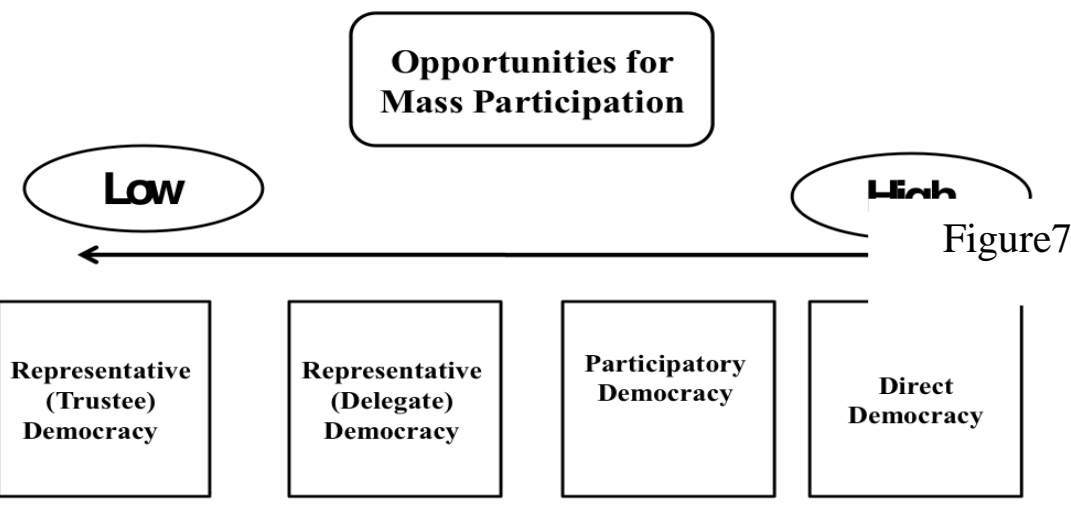


In Tunisian, the political system seemed unrelated to public opinion on the street and in different to social and Arab issues. In Libya, there was a lack of popular participation as it is not permitted by the authority's institutions, as well as the survival of some officials in their positions for up to 16 consecutive years and the state was not successful in the efficient use of available resources which resulted in Libya "a rich country with poor people".

With regards to freedom of speech and expression it could be obviously observed that all three countries still have a long way to go although moving from controlled media to "partly free" press and internet according to freedom house organization.

When examining democracy models for governance in MENA countries where revolutions took place in a bid to determine the required model to fulfill the revolution's goal of political change.

We come to the conclusion that the Elite Democracy model of governance is the most likely to succeed, although the trust in political elites has dropped in rich democracies ${ }^{38}$ and Although demands are increasing, in MENA countries, for maximizing mass participation, introducing the adoption of the majoritarian model, the Elite democracy model might be the most suitable for the time being due to several obstacles facing the implementation of the majoritarian model, of which the most important is Illiteracy, as there is a high rate of illiteracy in most MENA countries, $32.8 \%$ among men $\& 56.4 \%$ among women in 
$\sim$ Amany A. Khodair \& Mahmoud Khalifa

Egypt-2006, 16.9\% among men \& 36.9\% in Tunisia-2008, 8.2\% among men \& 29.3\% among women in Libya-2009, 9\% among men \& 25.8\%. ${ }^{39}$ Low economic activity rates (Egypt 48.8\%, Tunisia $48 \%$, Libya $52.8 \%$ and low political participation rates in most cases (voter turnout data for last parliamentary elections:Egypt - 2010 was 27.47\%, Tunisia - 2009 89.40\%, Libya 2007 $56 \%)^{41}$ show that opportunities for high mass participation has not yet developed in major MENA countries, as described by the figure (1) and asserted by figure (7).

Democratic governance introduced by the liberal model is not a choice also because it needs various aspects of political reform such as, the slow and steady development of political parties, civil society and interest groups as well as a better education to provide the tools needs for limiting government by civil and peaceful means as well as individual rights protection. In short, human capital development is one of the key routes to promoting democracy in the region. Education and higher standards of living are directly linked to stronger support of democracy and more favorable attitudes towards gender equality (a key component for citizenship and equal participation) ${ }^{42}$.But also a great deal of infra structure development will be needed as well as repairing decades of public-sector corrosion that may also prove problematic, but all three countries should work on redesigning their institutions of government, on the path of fulfilling requirements needed for achieving modern democracy 


\section{Reference}

* Amany A. Khodair, Associate professor of Political Science, Suez Canal University-Egypt.

**Mahmoud Khalifa, Assistant Lecturer of Political Science,Suez Canal University

1. Wayne Gabardi, Contemporary Models of Democracy, Polity, Vol. 33, No. 4 (summer, 2001), p.550.

2. Eva Sorensen \& Jacob Torfing, Making Governance Networks Effective and Democratic Through Metagovernance,Public Administration Vol. 87, No. 2, 2009,p. 247.

3. Cavatorta, Francesco (2009) 'Divided they stand, divided they fail': opposition politics in Morocco. Democratization, 16 (1). pp. 137

4. Scott Mainwaring, Democratic governance in Latin America, Stanford University press, 2010, p 1

5. Mahmoud Monshipouri and Ali Assareh, The New Middle East and the United States: What to Expect After the Uprisings? Insight Turkey Vol. 13 / No. 3 / 2011, p. 122.

6. Jonathan Haughton and Shahidur R. Khandker, Handbook on Poverty and Inequality, the world bank,2009, p. 198.

7. Pamela Blackmon, Rethinking Poverty through the Eyes of the International Monetary Fund and the World Bank, International Studies Review. Jun2008, Vol. 10 Issue 2, p179.

8. Fosu, AugustinKwasi.Inequality, Income, and Poverty: Comparative Global Evidence Inequality, Income, and Poverty: Comparative Global Evidence Inequality, Income, and Poverty,Social Science Quarterly (Blackwell Publishing Limited).Dec2010, Vol. 91 Issue 5, p1433.

9. Zouheir A Maalej, The 'Jasmine Revolt' has made the 'Arab Spring': A critical discourse analysis of the last three political speeches of the ousted president of Tunisia, Discourse \& Society 23(6) 679-700, 2012, p.687.

10. http://data.worldbank.org/country/tunisia 
11. http://www.ruralpovertyportal.org/country/statistics/tags/tunisia

12. Sarah Sabry, How poverty is underestimated in Greater Cairo, Egypt, Environment \&Urbanization , International Institute for Environment and Development (IIED). Vol 22(2), 2010, p.525.

13. Amal A. Kandeel, Egypt at a Crossroads Middle East Policy, Vol. XVIII, No. 2, Summer 2011,p.39

14. www.arabew.org .

15. www.hrw.org

16. Andreas Schedler, The Nested Game of Democratization by Elections, International Political Science Review, Vol.23, No. 1, Electoral Governance and Democratization. (Jan., 2002), p. 106.

17. http://www.freedomhouse.org/report/freedom-world/2010/egypt

18. Dale Sprusansky ,Assessing Tunisia's Elections, Washington Report on Middle East Affairs, Jan/Feb2012, Vol. 31, Issue 1

19. AkramKhalifa, JabeenBhatti, Elections show big step Tunisia took, Special for USA TODAY, USA Today, Oct 21, 2011

20. BohenihQawy, Do the election lead to democracy, the case of Tunisia, Democracy Journal, Al Ahram, Jan 2012

21. http://www.freedomhouse.org/report/freedom-world/2012/egypt-0

22. Christi L. Thornton \& Clarinsa V. Grives, The Contribution of the Arab Spring to the Role of Transitional Justice and Amnesty Laws, A Review of Tunisia, Egypt and Libya, works.bepress.com,Aug. 2012, p.35.

23. Ibid, p.44.

24. Tarek Amara and Christian Lowe, Huge Turnout in Tunisia's Arab Spring Election, 23 October 2011,

25. Daniele Bozzelli, Tatiana Iourieva, Belinda Kato, Chelsea Sayers, LIBYA: A CONFLICT DIAGNOSTIC, Carleton University, INAF 5203, 10/09/2012, p.4.

26. http://www.freedomhouse.org/report/freedom-world/2012/egypt-0

27. http://www.ahewar.org/debat/show.art.asp?aid=98946

28. Alla El- DeinTaha, The political corruption in the modern Egypt, Civic Dialogue, No. 145, 2006.

29. MowadAbd El- Fadeal, Corruption and its results in Arab world, Arab Future Journal, No.243, 1999, p 6. 
$\sim$ Amany A. Khodair \& Mahmoud Khalifa

30. Ibrahim El- Ghenay, The Administrative Corruption and the Public Employee, International Information Network, 2011.

31. http://cpi.transparency.org/cpi2012/results/

32. http://www.transparency.org/research/cpi/overview

33. http://www.un.org/en/documents/udhr/index.shtml\#a1

34. http://www.freedomhouse.org/country/tunisia

35. http://www.freedomhouse.org/country/libya

36. http://www.freedomhouse.org/country/egypt

37. Awad El- Hadad, The Corruption and the sustainable development: an analytical view to the reality in Libya, Benghazy University, 2009, p28

38. David H. Kamens, "Chapter 3 New citizens, new models of democracy: Theorizing the 'disconnect' between citizens and states", Barbara Wejnert, in (ed.) Democratic Paths and Trends (Research in Political Sociology, Volume 18), Emerald Group Publishing Limited, p.56.

39. United Nations statistics division, social indicators, indicators on illiteracy,http://unstats.un.org/unsd/demographic/products/socind/lit eracy.htm.

40. United Nations statistics division,social indicators, Indicators on income and economicactivity, 2009, http://unstats.un.org/unsd/demographic/products/socind/inc-eco.htm.

41. The International Institute for Democracy and Electoral Assistance (International IDEA), http://www.idea.int/vt/index.cfm.

42. Amaney A. Jamal, Reassessing Support for Islam and Democracy in the Arab World? Evidence from Egypt and Jordan, World Affairs, Vol. 169, No. 2 (Fall 2006), p.59. 